AGRICA: Journal of Sustainable Dryland Agriculture, 13 (2) 125-135 (2020)

ISSN-Online: 2715-4955; ISSN-Cetak: 2715-6613

DOI: https://doi.org/10.37478/agr.v13i2.754

\title{
POPULASI DAN INTENSITAS SERANGAN Pelopidas mathias (LEPIDOPTERA: HESPIRIDAE) PADA TANAMAN PADI SAWAH (Oriyza sativa L) DI KECAMATAN POCO RANAKA KABUPATEN MANGGARAI TIMUR
}

\author{
Yustina Meling dan Sri Wahyuni \\ Program Studi Agroteknologi Fakultas Pertanian Universitas Flores \\ Jl. Sam Ratulangi XX Paupire, Ende, Nusa Tenggara Timur \\ sriwahyuni4611@gmail.com
}

\begin{abstract}
Population And Attack Intensity of Pelopidas mathias (Lepidoptera: Hespiridae) in Rice (Oriyza sativa L) in Poco Ranaka District East Manggarai District. The high demand is not matched by production which increases to become the control in the business of rice cultivation. The cause of unsustainable rice production is the attack of Pilopidas matias. Loss due to P. mathias attacks is $20-75 \%$. The existence of $P$. mathias in Pocoranaka is also given special attention by that reason, the aim of this research is to determine the population and intensity of $P$. mathias in East Poco Ranaka sub-district, Kabupaten Manggarai.The variables used include the population and intensity of $P$. mathias in the lowland rice plant, the researcher showed the population of $P$. mathias in Compang Wesang village as many as 3,989 individuals with the category of intensity of heavy attack, namely $64.45 \%$ when compared to 1,643 larvae of the village. with less frequent intensity $32 \%$.
\end{abstract}

Keyword: Attack intensity, Pelopidas mathias, Population, Rice

PENDAHULUAN

Padi merupakan tanaman pangan yang menjadi makanan pokok di Indonesia, masyarakat Indonesia mengkonsumsi nasi sebagai sumber karbohidrat, sehingga pemenuhan kebutuhan padi menjadi salah satu tantangan terbesar karena populasi masyarakat Indonesia terus meningkat namun produksi padi belum pasti memenuhi kebutuhan tersebut (Anggraini, 2013).
Produktivitas padi Nusa Tenggara Timur sejak tahun 2014-2018 secara berurutan adalah 172,136 ton/ha, 188,092 ton/ha, 185,288 ton/ha, 220,623ton/ha, 241,204 ton/ha (BPPS, 2018). Sedangkan di Kabupaten Manggarai Timur, produktivitas padi tahun 2015 yaitu sebesar 0,42 ton/ha, tahun 2016 mengalami peningkatan mencapai 3,97 ton/ha. Sementara pada tahun 2017 penghasilan mencapai 3,74 ton/ha, terjadi penurunan produktivitas sebesar 
0,05 ton per hektar (BPS Manggrai Timur, 2017). Berdasarkan data pusat statistik kabupaten Manggarai Timur diketahui produktivitas padi di Kecamatan Poco Ranaka pada tahun 2017 adalah 3,50 ton/ha, sedangkan pada tahun 2018 adalah 3,34 ton/ha, artinya terjadi penurunan produksi padi sebesar 0,16 ton/ha (BPS, 2018). Salah satu faktor penyebab terjadinya penurunan produksi di Kecamatan Poco Ranaka adalah adanya organisme pengganggu tanaman (OPT) padi yang menyerang pada setiap musim tanam. Salah satu OPT tersebut adalah ulat penggulung daun atau Pelopidas mathias (Lepidoptera: Hesperiidae).

Pelopidas mathias merupakan hama yang menyerang tanaman padi baik pada musim hujan maupun kemarau. Tiga speseis hama lainnya selain $P$. mathias yang sefamili yakni $P$. gutata, $P$. mangala, dan $P$. heiriach ketiganya menyebar luas diseluruh Asia dan Afrika dan menyebabkan kerusakan serta kerugian besar (Litsinger et al., 1994). Serangan P. mathias di Jepang menyebabkan kerusakan yang mencapai ambang ekonomi (Litsinger et al., 1994). Sementara di Indonesia dilaporkan terjadi serangan di Kabupaten Subang, Provinsi Jawa Barat dimana P. mathias merupakan salah satu hama penting pada tanaman padi.

Masa yang paling berbahaya $P$. mathias adalah larva, karena menyerang tanaman padi mulai umur 2 minggu dengan cara menggulung daun dan akan memakan daun padi hingga terputus sehingga berkurangnya area fotosintesis pada daun padi yang selanjutnya padi kekurangan nutrisi sehingga mengakibatkan menurunnya produksi

Kecamatan Poco Ranaka terletak dibawah kaki gunung Ranaka, di Kabupaten Mangggarai Timur dengan luas areal pertanian sawah 2.479 ha. Berdasarkan hasil pengamatan diketahui bahwa dalam budidaya tanaman padi masyarakat masih menerapkan sistem pertanian konvensional. Sistem pertanian konvensional yang diterapkan seperti penanaman yang tidak serempak, pola tanam monokultur, pengolahan lahan secara manual, penggunaan pestisida berlebihan yang menyebabkan resistensi terhadap hama (Ermala, et al., 2017). Petani lebih banyak menggunakan pestisida (arivo) berbahan aktif sipermetrin dengan dosis 5-10 $\mathrm{gr} / \mathrm{m}^{2}$ untuk mengendalikan hama $P$. mathias pada umur 3 minggu setelah tanam (mts), serta saat padi mulai membentuk malai. Selain itu siklus penanaman padi 
Meling: Populasi dan intensitas serangan Pelopidas mathias (Lepidoptera: Hespiridae) pada tanaman padi sawa (Oziyza sativa $\mathrm{L}$ )

yang terus-menerus serta adanya gulma yang menjadi inang alternatif berdampak pada keberlangsungan hidup P. mathias yang terus meningkat karena ketersediaan makanan $P$. matias selalu terpenuhi (Sari et al., 2017).

Serangan hama $P$. mathias dimulai sejak tahun 2015 dan belum terdata secara baik. Oleh sebab itu, diperlukan suatu informasi yang akurat berkenaan dengan populasi dan tingkat serangan P.matias di alam. Informasi ini sangat berguna bagi pengambilan keputusan tindakan pengendalian yang akan digunakan khususnya apabila kondisi populasi $P$. matias di alam telah mencapai ambang ekonomi yang mengharuskan petani menggunakan aplikasi pestisida dalam pengendaliannya.

\section{METODE PENELITIAN}

\section{Tempat dan Waktu Penelitian}

Penelitian dilaksanakan di

Kecamatan Poco Ranaka, Kabupaten Manggarai Timur yang mencakup 2 lokasi yaitu Mandowasu dan Compang Wesang. Penelitian dilaksanaakan pada bulan Januari-April 2020.

\section{Bahan dan Alat Penelitian}

Bahan-bahan yang digunakan dalam penelitian ini adalah: alkohol
$70 \%$, aquades, tali rafia, patok, kertas label, kantong plastik dan karet gelang. Alat yang digunakan dalam penelitian ini adalah: alat tulis, kamera, higrometer, botol koleksi serangga, papan LKJ.

\section{Pelaksanaan Penelitian}

\section{Penentuan Lokasi Sampel}

Lokasi penelitian ditentukan berdasarkan metode purposive sampling yaitu memilih daerah sampel berdasarkan kriteria: luasan areal, pola tanam petani dan adanya kerusakan. Pengambilan sampel dilakukan di Kecamatan Poco Ranaka pada tempat yang telah dilakukan observasi yakni di Kelurahan Mandosawu dan Desa Compang Wesang dengan luas lahan 1 ha.

\section{Penentuan Areal Sampel}

Pengambilan sampel dengan metode jalur yaitu dengan jumlah 10 plot jarak 10 meter x 10 meter. Pengambilan sampel dilakukan sebanyak 2 kali dalam seminggu yaitu pada umur $3 \mathrm{mst}, 6 \mathrm{mst}$, dan 9 mts (minggu setelah tanam).

\section{Variabel Pengamatan}

\section{Populasi}

Penelitian dilakukan dengan cara mengambil seluruh larva yang terdapat pada tanaan sampel. Pengambilan sampel dilakukan pada tanaman umur 3 mts, 6 mts dan 9 mts. Perhitungan 
populasi menggunakan rumus menurut Fallis (2013).

$$
\mathrm{P}=\frac{a}{b}
$$

Keterangan:

$\mathrm{P}=$ Padatnya larva

$\mathrm{a}=$ Jumlah sampel yang ditemukan

dalam satu plot

$\mathrm{b}=$ Jumlah pengamatan

\section{Kerapatan}

Kerapatan ditetapkan berdasarkan jumlah populasi per satuan luas areal sampel menggunakan rumus menurut Magurran dalam Wahyuni (2017).

$$
\mathrm{RI}=\frac{S-i}{\ln N}
$$

Keterangan:

$\mathrm{RI}=$ Indeks kerapatan

$\mathrm{S}=$ Jumlah total instar yang ditemukan

$\mathrm{N}$ = Total larva yang ditemukan

\section{Intensitas Serangan}

Intensitas serangan di lihat dari seberapa parah serangan larva $P$. mathias yang tingkat keparahannya di konversi dengan nilai skor kerusakan. Kriteria nilai skor serangan yaitu tanaman yang tidak terserang (0), sudah terlihat larva di daun namun belum terjadi serangan (1), larva sudah mulai memakan daun padi (3), larva $P$. mathias, memakanseluruh bagian daun (5). Intensiatas serangan dapat dihitung menggunakan rumus menurut Defitri (2017).

$$
\mathrm{I}=\frac{\sum(n i . V i)}{N . V} \mathrm{X} 100 \%
$$

Keterangan :

I = Intensitas serangan

ni $=$ Jumlah tanaman dengan skor ke-i

$\mathrm{Vi}=$ Nilai skor serangan

$\mathrm{N}=$ Jumlah tanaman yang diamati

$\mathrm{V}=$ Skor tertinggi

Tabel 1. Klasifikasi tingkat kerusakan tanaman akibat serangan hama.

\begin{tabular}{ccl}
\hline $\begin{array}{c}\text { Klasifikasi tingkat kerusakan } \\
\text { serangan hama }\end{array}$ & $\begin{array}{c}\text { Tingkat serangan } \\
(\boldsymbol{\%})\end{array}$ & Kategori \\
\hline 0 & 0 & Sehat \\
1 & $1-20$ & Sangat sehat \\
2 & $21-40$ & Ringan \\
3 & $41-60$ & Sedang \\
4 & $61-80$ & Berat \\
5 & $81-100$ & Sangat berat \\
\hline
\end{tabular}


Meling: Populasi dan intensitas serangan Pelopidas mathias (Lepidoptera: Hespiridae) pada tanaman padi sawa (Oziyza sativa $\mathrm{L})$

\section{Analisis Data}

Data yang diperoleh dari lokasi penelitian ditabulasi menggunakan rumus populasi, kerapatan dan intensitas serangan kemudian dideskripsi sesuai dengan variabel pengamatan yang telah ditentukan.

\section{HASIL DAN PEMBAHASAN}

\section{Serangan Hama Pelopidas mathias}

Berdasarkan hasil pengamatan, serangan hama Pelopidas mathias pada tanaman padi sawah menyebabkan pertumbuhan daun terhambat sehingga proses fotosintesis terganggu dan berdampak bagi menurunnya produksi. Proses fotosintesis akan optimal apabila daun yang menjadi tempat utama terjadi proses fotosintesis berjumlah banyak, semakin besar ukurannya, serta intensitas sinar yang lebih tinggi intensitasnya (Pertamawati, 2010). Kerusakan yang di timbul oleh larva $P$. mathias dengan cara memotong dan menggulung daun, menyebabkan daun padi terlipat ke atas dengan menggunakan benang sutra dan memakan dari ujung daun hingga ke dalam dan yang tersisa hanya pelepah (Darmojo, 2016). Kondisi tersebut menyebabkan area fotosintesis berkurang. Larva $P$. mathias menyerang pada fase vegetatif hingga generatif, baik pada musim hujan maupun kering. Larva P. mathias paling banyak menyerang pada masa vegetatif dimulai pada umur 3 minggu setelah tanam.

\section{Populasi Hama Pelopidas mathias}

Hasil pengamatan populasi hama P. mathias di Kecamatan Poco Ranaka yaitu di Kelurahan Mandosawu (Md) dan Desa Compang Wesang (C W) berbeda pada setiap instar. Sebaran populasi setiap instar larva $P$. mathias dapat dilihat pada Tabel 2 berikut.

Tabel 2. Populasi dan presentase populasi larva Pelopidas mathias di Kelurahan Mandosawu dan Desa Compang Wesang

\begin{tabular}{ccccccc}
\hline \multirow{2}{*}{ Lokasi penelitian } & Fase & \multicolumn{5}{c}{ Waktu pengamatan } \\
\cline { 3 - 7 } & larva & $\mathbf{3 ~ m s t}$ & $\mathbf{6 ~ m s t}$ & $\mathbf{9 ~ m s t}$ & Total & Rata-rata \\
\hline Kelurahan & 1 & 253 & 102 & 186 & 541 & 180,33 \\
Mandosawu & 2 & 248 & 109 & 223 & 580 & 193,33 \\
& 3 & 225 & 125 & 172 & 522 & 174 \\
\hline Desa Compang & 1 & 556 & 420 & 355 & 1331 & 443,67 \\
Wesang & 2 & 384 & 602 & 346 & 1332 & 444 \\
& 3 & 306 & 452 & 568 & 1326 & 442 \\
\hline
\end{tabular}


Tabel 2 memperlihatkan populasi instar yang paling banyak ditemukan adalah instar-2 dan yang paling sedikit adalah instar-3. Melonjaknya populasi instar-2 menunjukan bahwa kebutuhan makanan yang paling banyak terjadi pada instar-2. Pada instar awal, serangga membutuhkan makanan sebagai energi untuk pertumbuhan. Proses pertumbuhan dan perkembangan di tandai dengan peningkatan berat badan dan panjang badan. Penurunan laju konsumsi makanan terjadi pada instar-3 yang berkenaan dengan adanya perubahan fisiologi larva untuk memasuki fase pupa. Aktivitas larva instar akhir cenderung menurun yang ditandai dengan menurunnya aktivitas gerak dan makan di ikuti dengan pemendekan dan pengkerutan panjang badan hal ini berarti larva memasuki fase puasa untuk berkosentrasi membentuk kekebalan kutikula stadium istirahat (Deasy et al., 2018).

Populasi larva $P$. mathias di Compang Wesang (3.999 ekor) dibandingkan populasi di Kelurahan Mandosawu (1.643 ekor). Perbedaan populasi hama di alam disebabkan oleh ketersediaan makanan, lingkungan yang mendukung, dan kurangnya musuh alami (Usyati et a.l, 2018).
Ketersediaan makanan di alam di pengaruhi oleh musim tanam dan pola tanam. Musim tanam di Kelurahan Mandosawu sebanyak 2 kali setahun sementara di Desa Compang Wesang adalah 3 kali dalam satu tahun. Perbedaan musim tanam di kelurahan Mandosawu dan desa Compang Wesang di duga dapat berpengaruh terhadap populasi P. mathias. Menurut (Rizal, 2018). Ketersediaan makanan yang selalu terpenuhi dalam setiap saat sangat mendukung perkembangan populasi hama. Sementara itu pola tanam yang diterapkan oleh petani di Kelurahan Mandosawu lebih rapat $(10 \mathrm{~cm}$ x $15 \mathrm{~cm})$ di bandingkan di Desa compang Wesang jarak tanam renggang $(20 \mathrm{~cm} \times 25 \mathrm{~cm})$. Jarak tanam yang dekat akan mempermudah bagi hama untuk menyebar dan mudah melindungi diri saat dilakukan pengendalian dengan cara penyemprotan insektisida, sedangkan jarak tanam yang renggang kesulitan untuk hama menyebar ( Ermala et al., 2017).

Lingkungan persawahan di Kelurahan Mandosawu lebih kompleks di bandingkan Desa Compang Wesang. Persawahan di Kelurahan Mandosawu di kelilingi oleh tanaman perkebunan berupa kopi, sementara di areal 
Meling: Populasi dan intensitas serangan Pelopidas mathias (Lepidoptera: Hespiridae) pada tanaman padi sawa (Oziyza sativa $\mathrm{L}$ )

persawahan juga di temukan jenis tanaman lain seperti kacang-kacangan serta tanaman liar lainnya yang menghasilkan bunga. Kondisi yang demikian tidak di temukan di areal persawahan Desa Compang Wesang. Kompleksitas tanaman penyusun lingkungan menjamin kestabilan ekosistem pada tingkat trofi berikutnya. Ketersediaan makanan (nektar) yang dihasilkan oleh jenis-jenis tanaman di sekitar areal tanaman di Kelurahan Mandosawu memberikan pengaruh baik terhadap keberadaan musuh alami seperti predator dan parasitoid. Keberadaan predator dan parasitoid di alam secara alami dapat menurunkan populasi larva $P$. mathias. Menurut (Rizal, 2018) musuh alami dapat mempengaruhi perkembangan hama di lapangan, karena keberadaan habitat liar yang menyediakan pakan dan tempat mengungsi bagi serangga penyerbukan musuh alami hama.

\section{Kerapatan Pelopidas mathias}

Hasil pengamatan kerapatan $P$. mathias di Kelurahan Mandosawu dan Desa Compang Wesang berbeda pada setiap instarnya. Sebaran kerapadatan setiap instar larva $P$ mathias dapat dilihat pada Tabel 3 berikut.

Tabel 3. Kerapatan Pelopidas mathias

\begin{tabular}{ccccc}
\hline Lokasi & $\begin{array}{c}\text { Fase } \\
\text { larva }\end{array}$ & Populasi $(\mathbf{N})$ & $\begin{array}{c}\text { Kerapatan } \\
(\mathbf{R i})\end{array}$ & Kategori \\
\hline Kelurahan & 1 & 1.331 & 0.33 & Rendah \\
Mandosawu & 2 & 1.332 & 0,33 & Rendah \\
& 3 & 1.326 & 0.33 & Rendah \\
\hline Desa Compang & 1 & 547 & 0,33 & Rendah \\
Wesang & 2 & 522 & 0.32 & Rendah \\
& 3 & 580 & 0.35 & Rendah \\
\hline
\end{tabular}

Tabel 3 menjelaskan kerapatan $P$. mathias di Kelurahan Mandosawu dan Desa Compang Wesang menunjukan kerapatan rendah disebabkan oleh kapasitas ekologi masih bagus untuk menampung kehidupan larva $P$. mathias karena kelimpahan makanan dan areal yang luas.
Penyebab kerapatan hama adalah pengaruh jarak tanam. Faktor jarak tanam yang berdekatan mengakibatkan jumlah populasi hama tinggi. Populasi hama yang tinggi menyebabkan terjadinya persaingan akan kebutuhan nutrisi yang berasal dari tanaman. Floem tanaman berisi seperti larutan sebagian 
besar berisi gula, asam amino dan senyawa fenolik (Ratna et al., 2011). Nutrisi esensial dibutuhkan oleh serangga untuk bertumbuh kembang, pemeliharaan jaringan, reproduksi, dan sebagai energi (Susrama, 2017).

Faktor lain yang mempengaruhi kerapatan adalah temperatur habitat yang sesuai dapat membantu perkembangan aktifitas dan reproduksi serangga. Suhu di lokasi penelitian berkisar antara 27-32 ${ }^{\circ} \mathrm{C}$ dan kelembaban mencapai $70 \%$ di duga mampu membantu perkembangan larva dan pupa. Menurut (Nuriyanti et al., 2017) suhu yang sesuai memperngaruhi perkembangan larva dan adalah berkisar 27-29 ${ }^{\circ} \mathrm{C}$. Habitat yang sesuai ini mampu meningkatkan kemampuan-kemapuan individu populasi yang mempengruhi kerapatan adalah sifat penyebaran hama dan kemapuan mencari inang.

\section{Intensitas Serangan Pelopidas mathias}

Hasil pengamatan intensitas serangan $P$. mathias di Kelurahan Mandosawu dan Desa Compang Wesang berbeda. Sebaran intensitas serangan di Kelurahan Mandosawu dan Desa Compang Wesang dapat dilihat pada Tabel 4

Tabel 4. Intensitas serangan larva $P$. mathias di Kelurahan Mandosawu dan Desa Compang Wesang

\begin{tabular}{ccc}
\hline Lokasi & Intensitas serangan & Rerata \\
\hline Mandosawu & Ringan & $32 \%$ \\
Compang Wesang & Berat & $64,35 \%$ \\
\hline
\end{tabular}

Tabel 4 yang disajikan diatas memampilkan tingkat serangan larva $P$. mathias berbeda. Larva $P$. mathias mengakibatkan serangan ringan di Kelurahan Mandosawu sedangkan di Desa Compang Wesang terjadi serangan berat.

Berdasarkan hasil penelitian intensitas serangan ringan yang disebabkan oleh larva P.mathias di Kelurahan Mandosawu di duga karena perlakuan pengendalian yang di terapkan sehingga populasi larva $P$. mathias berkurang. Hal ini terbukti dari hasil wawancara dengan petani setempat yakni di Kelurahan Mandosawu melakukan pengendalian dengan cara penyemprotan pestisida. Petani menggunakan pestisida (Arrivo) berbahan aktif sipermetrin. Pengendalian di lakukan sebanyak 1 kali dalam 2 minggu secara rutin dengan tujuan untuk menekan populasi larva $P$ mathias. Pengaruh lain yang di temukan saat 
Meling: Populasi dan intensitas serangan Pelopidas mathias (Lepidoptera: Hespiridae) pada tanaman padi sawa (Oziyza sativa $\mathrm{L}$ )

penelitian adalah hujan yang secara terus-menerus. Menurut Pratiwi et al. (2013) pengaruh faktor iklim yang tidak mendukung dapat mempengaruhi intensitas serangan di lapangan. Selain itu pengaruh predator yang memangsa larva pada setiap fase instar. Predator yang paling banyak di temukan di lokasi penelitian adalah laba-laba. Laba-laba sering memangsang larva pada instar 12.

Serangan berat yang disebabkan oleh larva $P$. mathias Desa Compang Wesang di asumsikan karena perlakuan pengendalian yang tidak teratur misalnya penyiangan, dan jarak tanam yang tidak teratur seperti yang di lakukan di Kelurahan Mandosawu. Hal ini menyebabkan larva $P$. mathias menyukai lokasi ini sehingga kepadatan populasi tinggi dan menyebabkan kerusakan yang paling tinggi. Hasil penelitian Yuliani (2020) hama lebih banyak menyerang di lokasi yang perlakuan bersifat organik di bandingkan dengan nonorganik. Pengaruh lain yang ditemukan adalah kelimpahan inang bagi larva $P$. mathias. Sitem pertanian secara monokultur di lahan yang sama akan menyebabkan kelimpahan inang dan kebutuhan makanan yang sesuai bagi pertumbuhan dan perkembangan larva $P$. mathias.

\section{SIMPULAN}

Berdasarkan hasil penelitian ini dapat disimpulkan:

1. Populasi larva $P$. mathias di Kelurahan Mandosawu 3.989 ekor sedangkan di Desa Compang Wesang 1.643 dan instar yang paling banyak di temukan adalah instar 2.

2. Larva $P$. mathias di Desa Compang Wesang mengakibatkan serangan berat dengan presentase serangan $64,35 \%$ sedangkan di Kelurahan Mandosawu terjadi serangan ringan dengan presentase $32 \%$.

\section{UCAPAN TERIMAKASIH}

Ucapan terimakasih yang sebesar-besarnya penulis sampaikan kepada kedua ibu Dr. Sri Wahyuni dan Bapak Dr. Willybrordus Lanamana atas masukan, kritik dan sarannya sehingga tulisan ini layak untuk dipublikasikan.

\section{DAFTAR PUSTAKA}

Anggraini, F. 2013. Sistem Tanam Dan Umur Bibit Pada Tanaman Padi Sawah (Oryza sativa L .) Varietas INPARI 13. Jurnal Produksi Tanaman, 1(2), 52-60.

BPS Kabupaten Manggarai Timur. (2017). Statistik Pertanian Indonesia. 
BPS Nasional. 2018. Kementerian Pertanian Republik Indonesia. Bps Nasional Indonesia.

Darmojo, B., Palmer, T. 2016. Perpustakaan Universitas Indonesia. Buku Teks. International Journal of Adolescence and Youth, 3(1), 2739.

Deasy V. C. M., Nismah N., Suratman U. 2018. Kemampuan Berbagai Tingkatan Stadium Larva Kumbang Tenebrio Molitor L.(Coleoptera :Tenebrionidae) Dalam Mengkonsumsi Styrofoam ( Polystyrene ) 5(1), 83-88.

Ermala I. L., Suhartini, Triatmanto. 2017. Pengaruh Pola Tanam Padi (Oryzasativa . L) Kultivar Inpari Sidenuk Terhadap Keanekaragaman Jenis Hama Di Kelompok Tani Manunggal Patran Desa Madurejo.. J Prodi Biologi. 6 ( 7), 409-416.

Fallis, A. 2013. Ekologi dan Sistem Peramalan Hama.Journal of Chemical Information and Modeling, 53(9), 1689-1699.

Litsinger J.A., Bumroongsri V., M. W. L. S. O. 1994. Rearing, Developmental Biology And Host Plant Range Of The Rice Skipper Pelopidas Mathias $(F)$ (Lepidoptera : Hesperiidae). Rice skipper biology weedhosts (1).

Nuriyanti, D. D., Widhiono, I., Suyanto, A. 2017. Faktor-Faktor Ekologis yang Berpengaruh terhadap Struktur Populasi Kumbang Badak (Oryctes rhinoceros L.). J Biosfera, 33(1), 13-21.
Pertamawati. 2010. Pengaruh Fotosintesis Terhadap Pertumbuhan Tanaman Kentang (Solanum Tuberosum L.) Dalam Lingkungan Fotoautotrof Secara Invitro. J Sains dan Teknologi Indonesia. Vol.12 (1) 31-37.

Pratiwi S., Noni W., Caroulus R, M. G.2013. Populasi Dan Intensitas Serangan Hama Putih (Nymphula Depunctalis Guene) Pada Tanaman Padi Sawah Di Kecamatan Dumoga Timur Kabupaten Bolaang Mongondow $1-8$.

Ratna. 2011. Pengaruh Konsentrasi Subletal Deltametrin Terhadap Nutrisi Dan Pertumbuhan Tanaman Padi. J Perlindungan Tanaman Indonesia, 17(2), 47-53.

Rizal M., Siswanto. 2018. Pengelolaan Komunitas Serangga Hama Dan Serangga Berguna Untuk Peningkatan Produktivitas Jambu Mete.J Perspektif 17(1), 1-14.

Sari P., Syahribulan., Sjam S., S. S. 2017. Analisis Keragaman Jenis Serangga Herbivora Di Areal Persawahan Kelurahan Tamalanrea Kota Makassar. J Biologi Makassar, 2(1), 35-45.

Susrama, I. G. K. 2017. Kebutuhan Nutrisi dan Substansi dalam Pakan Buatan Serangga. E- Jurnal Agroekoteknologi Tropika, 6(3), 310-318.

Usyati, N., Kurniawati, N., dan Ruskandar, A. 2018. Populasi Hama dan Musuh Alami pada Tiga Cara Budidaya Padi Sawah di Sukamandi. J Agrikultura. 29(1), 35-42. 
Meling: Populasi dan intensitas serangan Pelopidas mathias (Lepidoptera: Hespiridae) pada tanaman padi sawa (Oziyza sativa $\mathrm{L})$

Wahyuni S., Wayan I Supartha., Ubaidillah Rosichon., Nyoman I Wijaya . 2017. Struktur komunitas parasit penambang daun Liriomyza spp. (Diptera: Agromyzidae) dan laju parasitisasi pada tanaman sayuran di Kepulauan Sunda Kecil, Indonesia. J Biodiversitas.18(2), 593-600.
Yuliani, Ad. P. A. 2020. Kepadatan Populasi Dan Intensitas Serangan Wereng Batang Coklat (Nilaparvata Lugens . Stal) Pada Budidaya Padi Pandanwangi Dengan Penerapan Organik Dan Anorganik. J Pro-Stek. 2(1), 4956. 